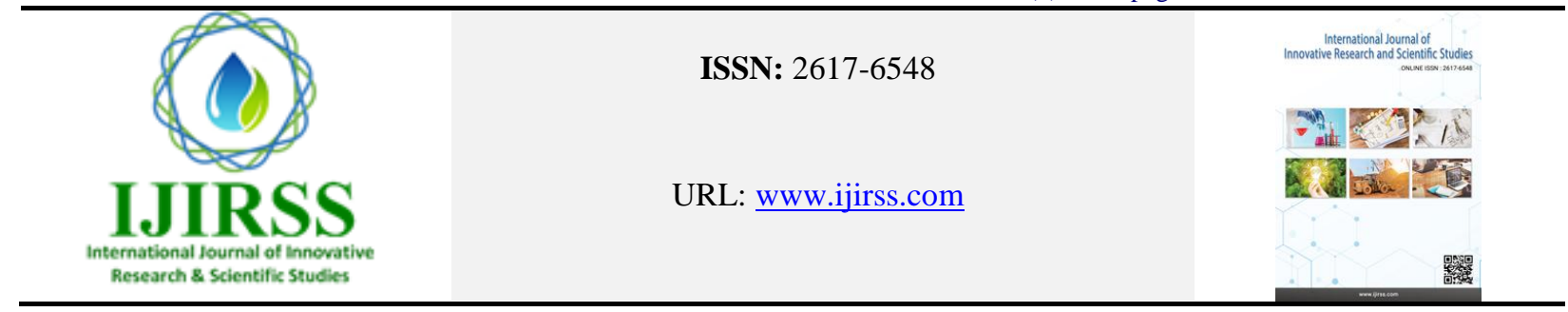

\title{
Factors Affecting Audit Professional Ethics - Approach from the Perception of Auditors in Vietnam
}

\author{
Le Doan Minh Duc
}

University of Economics Ho Chi Minh City, Vietnam.

Email:_ucldm@ueh.edu.vn

\begin{abstract}
Auditor independence is one of the most important attributes of audit professional ethics. This article delivers a full insight into the perception of auditors about independence in the auditing activities in Vietnam. The article approaches from the auditor's perception in the actual working environment. The article uses a mixed approach based on the experimental methodology. The article uses the archival research method and group discussions method to analyze and assess the research problems and verify by experimental data. The article takes the group discussions with experts and surveys 300 directors, auditors, auditor assistants who are working in 70 auditing firms. The results show that perception of independence is affected by moral awareness, working environment, and professional Association. Factors affecting auditors' independence from moral awareness of auditor include perception of utilitarianism, perception of deontology; perception of egoism. Factors affecting auditor's independence from working environment: business philosophy, management practices. Factors relating to the professional association as orientation, supervision, risk of audit practice. In particular, factors relating to the risk of audit practice do not promote the preservation of auditor independence due to the low litigation risks in the Vietnamese auditing environment while the remaining factors motivate auditors to increase their independence. The article implies that the auditors, the audit firms, and the Association of Certified Public Accountants should possess appropriate orientations and policies to raise the perception of auditor independence. Thereby, auditors will improve their attitude and behavior to ensure independence.
\end{abstract}

Keywords: Auditor independence, Moral awareness, Audit firm, Audit process, Professional ethics, Perception of auditors.

JEL Classification: M42.

DOI: 10.53894 ijirss.v4i4.201

Funding: This research is funded by University of Economics Ho Chi Minh City, Vietnam.

History: Received: 2 August 2021/Revised: 6 September 2021/Accepted: 12 October 2021/Published: 22 November 2021

Licensed: This work is licensed under a Creative Commons Attribution 4.0 License $(\mathrm{cc}) \mathrm{EY}$

Competing Interests: The author declares that there are no conflicts of interests regarding the publication of this paper.

Transparency: The author confirms that the manuscript is an honest, accurate, and transparent account of the study was reported; that no vital features of the study have been omitted; and that any discrepancies from the study as planned have been explained.

Ethical: This study follows all ethical practices during writing.

\section{Introduction}

Auditor independence is one of the most important attributes of audit professional ethics. During the process of audit performance, the auditors need to maintain an objective view, honesty, and professional skepticism (independence in mind) and provide safeguard measures against declining independence for the situations that may jeopardize it (independence in 
appearance) [1]. Furthermore, the auditor must have a righteous, unbiased viewpoint in the process of performing audit, analyzing the results, approving the audit report $[2,3]$ as well as the ability to withstand the pressure from management influences so that the integrity is not compromised $[4,5]$.

Recently, there have been many studies devoted to the issue of auditor independence from a variety of perspectives. Normally, studies follow one of the four approaches: economic approach, behavioral approach, risk approach, and model approach. Studies that conduct (i) an economic approach based on an auditor-client relationship via the service contract between the audited firm and the audit firm. Thence, the auditors may depend on the client to generate economic benefits through the fees charged for the audit service and the fees that are not related to the audit services [6-9]. (ii) Behavioral research assumes that both auditor and client are closely related and interacting with each other while performing the audit services [1012]. This problem leads to many situations that affect the auditor independence such as selection audit firms, appointment of the auditors, audit tenure, ability of the auditors to protect their clients. Additionally, many studies approach (iii) the risk of lost independence from motivation causing auditors to violate ethical standards and principles in pursuing opportunistic situations in which professional judgment becomes biased and lacks integrity [13-16]. Finally, recent studies use (iv) model approach to investigate auditor independence which is regulated and guided by standards on auditing and professional ethics issued by IFAC [1]. This approach originates from basic ethical principles that shape the independence; [17-22].

There are many studies on the topic of auditor independence. The following studies are inherited from previous studies. Therefore, the article presents some representative or recently published studies.From the analysis of the studies in line with the four approaches, the article found that there has been a research gaauditor $p$ in the issue of auditor independence based on the approach to auditor's perception. Individual perception influences a person's attitude, thereby also influences his or her own behavior [23]. Consequently, the auditor's perception of independence is the most important stage for his or her to carry out a high-quality audit through maintaining independence. Since then, the article conducted this study based on the auditor's ethical perception to achieve the following objectives (O1): to identify the factors affecting the auditor independence due to their moral awareness and (O2) to assess the the degree of impact of those factors on the auditor independence in the actual working environment.

\section{Research Methodology}

The article uses a mixed approach based on the methodology framework of Olalere [24]. The article uses the archival research method and group discussions method to analyze and assess the research problems and verified by experimental data. Our research subject is the independence of auditors working in Vietnamese audit firms. The article reviews previous studies to identify the factors affecting auditor independence that are consistent with auditor's perception in the working environment in Vietnam. After that, the article uses the method of expert group discussions to reaffirm the factors identified at the preliminary stage. The article selected 11 experts, who are directors and auditors of audit firms to participate in our expert group discussions. Due to the interaction and the level of expertise of the experts, the value of answers is increased, and many valuable new ideas are formed. Since the discussion outline is developed within the issue of auditor independence as the research objective, the article expects the results of expert group discussions are useful to test the new ideas, to (re)define the concepts of auditor independence. Meanwhile, the expert group discussions helped us develop hypotheses and design questionnaires to survey; confirm the factors; and build the research model. The identified factors can correlate with each other in addition to the impact on auditor independence because they originate from auditor's ethical perception and are affected by the work environment. Therefore, the article uses the structural regression model (PLS SEM) to measure the impact of these factors on auditor independence. The estimation results are to be determined after testing the reliability of data and the suitability of the research model.

\section{Literature Review}

In consistence with the research objectives, the article has carefully reviewed the case studies of independent auditors in line with the research topic and following the research approaches to see the current overall picture on the perception of the auditors about their independence.

\subsection{Auditors' Perception of Deontology, Egoism and Utilitarianism}

Considering from an ethical perspective, auditor independence includes the auditor's behavioral range from attitude to behavior during the audit process. So that the article can determine whether the auditor is really independent. The auditor's professional ethics arises from the auditor's perception and then moves to the auditor's attitude and behavior. Attitude is associated with independence in mind while behavior can manifest independence in appearance. Therefore, perception of deontology, egoism and utilitarianism will constitute auditor independence.

\subsubsection{Perception of Deontology}

The word "deontology" comes from the Greek words for the task ("deon") and science ("logo"). Deontology theory is a moral theory that guides and assess how people choices and do. Auditor independence, when considered from an ethical perspective, is related to the moral obligations, responsibilities regardless of the consequences of a behavior. Therefore, an action is considered ethical if it conforms to ethical principles [25]. The focus of ethics is not on the results of an action, but on 
the actions itself [26, 27]. Being aware of the important role of ethics in audit work, auditors will strive to enhance their independence. Therefore, the article hypothesizes H1 as follows:

H1: There is a positive impact of perceptions of deontology on auditor independence.

\subsubsection{Perception of Egoism}

Egoism theory was pioneered by Thrasymacus (c. 459-400 BC). Later, it was followed by modern thinkers like Thomas Hobbes (1588-1679) and philosopher Ayn Rand (1905-1982). These authors argued that people often use practical calculations to create themselves greatest benefit. The pursuit of personal interests is considered as leading to the interests of the society. Therefore, self-interest is a prerequisite for self-respect and respect for others.

Selfishness and pragmatism are the same because they are based on the results of the work rather than the capacity [28]. The goal of selfishness is to maximize personal gain when making any decision and carrying out any action. Thus, individual actions serve own short-term or long-term interests [28, 29]. From this point of view, the article hypothesizes that during the audit process, the auditors are clearly aware of the selfishness and show a more positive attitude and behavior in their reviews, considerations, and opinions. So, the article hypothesizes that the perceptions of selfishness have a positive effect on auditor independence.

H2: There is a positive impact from perceptions of Egoism on auditor independence.

\subsubsection{Perception of Utilitarianism}

The utilitarianism theory was developed by the ancient Greek philosopher Epicurus of Samos (341-270 BC), english philosopher Jeremy Bentham (1748-1832) and John Stuart Mill (1806-1873). The utilitarian theory is considered as the basis for making ethical decisions in business [30]. This theory is one of the most popular approaches to making ethical decisions, especially those with consequences involving large groups of people. This theory instructs people to weigh the good and the bad stemming from their actions. Utilitarianism reflects the moral acceptability of an action resulting from its outcome. If the results are good, the action is considered ethical. Otherwise, it is unethical [29]. Therefore, the article hypothesizes that perceptions of utilitarianism are likely to have a positive effect on auditor independence.

H3: There is a positive impact from the perception of utilitarianism on auditor independence.

\subsection{Ethical Perception of Auditors in the Audit Firms' Environment}

The auditors work full-time in the audit company with the position of employees or partners. Auditors are paid and are assigned tasks by managers of the audit companies. Although the auditors have independently commented on the presentation of the financial statements (reports), they are still governed by the work environment of the audit firms. The business philosophy and management practices will affect the auditor's perception of independence.

\subsubsection{Business Philosophy}

Business philosophy embodies the ideals of leadership, vision, mission, orientation and goals that guide operations and create a cultural and ethical environment for business. Business philosophy also includes principles, respect, and commitment to employees. In audit firms, the business philosophy is oriented towards developing high-quality audit based on compliance with professional ethics [1]. Business philosophy not only drives the leaders' attitude and behavior, but it also guides the employees in planning and implementation of work. Thence, the article can hypothesize that:

H4: Business philosophy raises the perception of auditor independence.

\subsubsection{Management Practices of Audit Firms}

Management practices refer to the simultaneous application of the principles related to planning, organizing, leading and controlling functions to effectively exploit physical, financial, human and informational resources to achieve organizational goals by applicable laws and social norms. In audit firms, the managers use the division of labor, the audit process, the review process, the quality control process to perform the auditor independence [1]. So that, they can achieve the highest quality of the audit services following the business philosophy and goals based on compliance with professional ethics. Obviously, the companies that perform good management practices will likely increase the auditor's perception of audit ethics within their work. Therefore, the article hypothesizes:

H5: Management practices raise the perception of auditor independence.

\subsection{Ethical Perception of Auditors Due to Control of Professional Association}

All the auditors must pass the examinations organized by the State and Professional Association to be granted an auditor's certificate [1]. Annually, all auditors must register to practice when they meet all conditions, such as working full-time at the audit company, update sufficient knowledge of accounting and auditing, good compliance with professional ethics. All auditors are subject to supervision and inspection by the Association. Association often takes the audit quality test annually. Auditors can be sanctioned according to the extent of their violations of professional ethics. Therefore, the perception of professional ethics, especially auditor independence, is affected by the orientation and control of the Association of Certified Public Accountants (ACPA). 


\subsubsection{Orientation and Supervision of ACPA}

ACPA conducts quality control of audit firms and auditors annually [1]. The results of control will classify whether the firms and/or auditors are qualified to perform audit works. If the given audit firm or auditor fails to meet the quality standards, they may be suspended from the practice or handled for administrative violations. Once such an incident occurs, audit firms and auditors lose their professional reputation which is the most valuable asset. Moreover, professional associations are monitoring issues and situations as they unfold that may affect the financial statements and audit reports [31].Therefore, the supervision and control executed by the professional association may increase the auditor's perception of the auditor independence.

Hypothesis H6: Monitoring and control of ACPA increase the perception of auditor independence.

\subsubsection{Risk of Auditors}

During the professional audit activities, the auditors may face risks [1] related to the withdrawal and suspension of practicing certificate, administrative sanctions, or even lawsuits. Beside, auditors also meet the legal liability for a case involving an audit failure [32]. Therefore, the perception of these risks helps auditors enhance specific attitudes and behaviors that increase their independence.

H7: The risk of audit practice increases the perception of auditor independence.

\section{Research Results and Discussion}

\subsection{Identifying Factors Affecting the Auditor Independence}

Based on the previous studies, the article has successfully identified factors that affect auditor independence. The article has conducted expert group discussions with 11 people, among them are 05 directors of the audit firm, 06 auditors and 04 auditor assistants. Thence, the article identifies or even to redefine factors affecting the auditor independence that are relevant to the scope of research in Vietnam. The determinant factors that are likely to affect the auditor independence are as follows Table 1:

Table-1.

Factors affecting the auditor independence.

\begin{tabular}{|c|c|c|}
\hline Perception of Deontology & \multirow{3}{*}{ Perception of professional ethics } & \multirow{7}{*}{$\begin{array}{l}\text { Perception of auditor } \\
\text { independence }\end{array}$} \\
\hline Perception of Egoism & & \\
\hline Perception of Utilitarianism & & \\
\hline Business philosophy & \multirow{2}{*}{$\begin{array}{l}\text { Ethical perception from the audit company's } \\
\text { environment }\end{array}$} & \\
\hline Management practice & & \\
\hline Orientation and Supervision & \multirow{2}{*}{$\begin{array}{l}\text { Ethical perception from the direction and control of } \\
\text { professional Association }\end{array}$} & \\
\hline Practicing risks & & \\
\hline
\end{tabular}

The expert group discussions have helped us in developing research hypotheses, building scales, designing questionnaires (see: Appendix 1), build the research model. The article has conducted surveys by implementing convenient sampling. The number of votes sent out is 320 , the number of votes received is 320 . After screening the questionnaires, excluding 20 inappropriate votes due to incomplete content, the remaining 300 suitable questionnaires were synthesized and analyzed by SPSS and AMOS software.

\subsection{Data Verification}

The article has surveyed a sample of 300 observations from 300 directors, auditors, auditor assistants who working at Vietnamese audit firms Table 2. Accordingly, the gender is relatively balanced, consistent with the characteristics of the audit profession. Additionally, all of them have university graduate or postgraduate degrees (university graduate: $74.3 \%$, university postgraduate: $25.7 \%$ ), meeting the statutory criteria. Especially, in term of seniority, about $3 / 4$ of them has been working and active in the profession for more than 05 years $(76.3 \%)$. So, the survey sample is highly reliable and suitable for the research objectives.

Table-2.

Describe observations

\begin{tabular}{l|c|c}
\hline Observe & Frequency & Percent \\
\hline Sex & 300 & 100 \\
\hline Male & 164 & 54.7 \\
\hline Female & 136 & 45.3 \\
\hline Seniority & 300 & 100 \\
\hline Less than 5 years & 71 & 23.7 \\
\hline 5-10 years & 128 & 42.7 \\
\hline
\end{tabular}




\begin{tabular}{c|c|c}
\hline Observe & Frequency & Percent \\
\hline $10-15$ years & 67 & 22.3 \\
\hline Over 15 years & 34 & 11.3 \\
\hline Level & 300 & 100.0 \\
\hline University & 223 & 74.3 \\
\hline Postgraduate & 77 & 25.7 \\
\hline
\end{tabular}

Thereafter, the article has assessed the suitability of the estimates using the Cronbach's Alpha coefficient evaluation. The estimates are reliable when the values of Cronbach's Alpha values are within the range of $[0.7,1.0]$ and total correlation coefficient $>=0.3$ [33]. From the results in Table 3, the article sees that estimates are reasonable and reliable.

Table-3.

Summary of measurement.

\begin{tabular}{|c|c|c|c|}
\hline Group of variables & Cronbach's alpha & Variables & Corrected item-total correlation \\
\hline \multirow{3}{*}{ Utilitarianism } & \multirow{3}{*}{0.745} & Utilitarianism1 & 0.793 \\
\hline & & Utilitarianism2 & 0.516 \\
\hline & & Utilitarianism1 & 0.439 \\
\hline \multirow{3}{*}{ Deontology } & \multirow{3}{*}{0.930} & Deontology1 & 0.923 \\
\hline & & Deontology2 & 0.868 \\
\hline & & Deontology1 & 0.780 \\
\hline \multirow{3}{*}{ Egoism } & \multirow{3}{*}{0.890} & Egoism1 & 0.717 \\
\hline & & Egoism2 & 0.863 \\
\hline & & Egoism3 & 0.781 \\
\hline \multirow{3}{*}{ Philosophy } & \multirow{3}{*}{0.753} & Philosophy1 & 0.600 \\
\hline & & Philosophy2 & 0.663 \\
\hline & & Philosophy3 & 0.490 \\
\hline \multirow{4}{*}{ Management } & \multirow{4}{*}{0.855} & Management1 & 0.754 \\
\hline & & Management2 & 0.655 \\
\hline & & Management3 & 0.627 \\
\hline & & Management4 & 0.778 \\
\hline \multirow{4}{*}{ Monitoring } & \multirow{4}{*}{0.731} & Monitoring1 & 0.465 \\
\hline & & Monitoring2 & 0.501 \\
\hline & & Monitoring3 & 0.531 \\
\hline & & Monitoring4 & 0.595 \\
\hline \multirow{3}{*}{ Risk } & \multirow{3}{*}{0.701} & Risk1 & 0.519 \\
\hline & & Risk2 & 0.509 \\
\hline & & Risk3 & 0.528 \\
\hline \multirow{3}{*}{ Independence } & \multirow{3}{*}{0.869} & Independence1 & 0.705 \\
\hline & & Independence2 & 0.789 \\
\hline & & Independence 3 & 0.757 \\
\hline
\end{tabular}

Explain the above variables as follows: Utilitarianism: Auditors's perception of Utilitarianism; Deontology: Auditors's perception of deontology; Egoism: Auditors's perception of Egoism; Philosophy: Business philosophy of audit firms; Management: Management practices of audit firms; Monitoring: Monitoring and control of Association of Certified Public Accountants; Risk: Risk of audit practice; Independence: auditor independence.

The article analyzes the EFA factor. The article examines the convergence of the observed variables Appendix 2. The authors find that the factor analysis is appropriate when KMO coefficient is in $[0.5,1]$ and $\mathrm{Sig}=0.000<0.5$. The results in Table 4 meet these standards.

Table-4.

KMO and Bartlett's Test.

\begin{tabular}{l|l|c|c}
\hline \multicolumn{2}{|c|}{} & Dependent variable & Independent variables \\
\hline \multicolumn{2}{l|}{ KMO value } & 0.727 & 0.677 \\
\hline \multirow{2}{*}{ Bartlett's Test of Sphericity } & Approx. Chi-Square & 451.205 & 3385.320 \\
\cline { 2 - 4 } & Df & 3 & 253 \\
\cline { 2 - 4 } & Sig & 0.000 & 0.000 \\
\hline
\end{tabular}


To assess the suitability of the model with market data, researchers are often interested in chi square/df indices, the Tucker-Lewis index (TLI), CFI comparative index, RMSEA - an important indicator to determine the suitability of the model against the overall. In some case studies, they distinguish two cases: chi-square/df $<5$ (with sample $\mathrm{N}>200$ ); or $<3$ (when sample size $\mathrm{N}<200)$, the model is considered good. Our sample size is 300 ( $>>200)$, so if the model receives chi-square/df $<5$ (also known as cmin/df $<5$ ), the TLI, CFI $\geq 0.9$, RMSEA $\leq 0.08$ then the model is considered suitable. Table 5 presents the confirmatory factor analysis $(\mathrm{CFA})$. Results $\mathrm{CMIN} / \mathrm{DF}=2.028<5, \mathrm{CFI}=0.925>0.9$, RMSEA $=0.059<0.08$ reflected that the pattern was consistent.

Table-5.

Confirmatory factor analysis.

\begin{tabular}{l|c|c|c}
\hline Model & CMIN/DF & CFI & RMSEA \\
\hline Default model & 2.028 & 0.925 & 0.059 \\
\hline Saturated model & & 1.000 & \\
\hline Independence model & 12.480 & 0.000 & 0.196 \\
\hline
\end{tabular}

From the appropriate model test results above, the article has estimated the regression model for the auditor independence. Hence, it can be argued that all the factors affecting the auditor independence are in the order of importance and degree as presented in the Table 6.

Table-6.

Factors affect auditor independence.

\begin{tabular}{l|c|c}
\hline Factors & Dimensional impact & Impact level \\
\hline 1. Philosophy & + & 0.264 \\
\hline 2. Monitoring & + & 0.093 \\
\hline 3. Deontology & + & 0.060 \\
\hline 4. Management & + & 0.054 \\
\hline 5. Egoism & - & 0.045 \\
\hline 6. Utilitarian & + & 0.031 \\
\hline 7. Risk & - & 0.020 \\
\hline
\end{tabular}

Assuming that all other factors are constant, the direction of the impact of the above factors on auditor independence is consistent with the original hypotheses $\mathrm{H} 1, \mathrm{H} 3, \mathrm{H} 4, \mathrm{H} 5, \mathrm{H} 6$.

Both the hypotheses $\mathrm{H} 2$ and $\mathrm{H} 7$ are rejected due to the finding that the perception of Egoism and the perception of practicing risks inversely affect auditor independence. This direction of impact may stem from the low-risk audit environment in Vietnam. All the published audit offenses mainly relate to the audit practice registration, the time of updating unsecured knowledge and the inappropriate professional judgments. Meanwhile, the audit irregularities affecting the decision of users of information in financial statements have not been clearly defined and disclosed. Therefore, the auditor's perception of Egoism and professional risks does not increase independence in the present context.

\section{Conclusions and Implications}

Auditor independence is one of the most important attributes of audit professional ethics. Intending to contribute to the theoretical development of the researched issue, the article has identified and estimated the model of factors affecting auditor independence following the auditor's perceptual approach to audit activities in Vietnam. In addition to the factors inherited from previous studies that have been adapted to fit the audit practices in Vietnam, the article has discovered new factors relating to the auditor independence in Vietnam: perception of the auditor's deontology, egoism and utilitarianism during the audit practices; business philosophy of audit firms. The results form a solid basis for the development of further studies that would identify other specific factors. Moreover, practical contributions also are made throughout. It is suggested that the auditors need to raise their perception of professional ethics in the audit process to maintain independence. Additionally, in the context of Vietnam's economy integrating deeply with the world, all auditors need to proactively improve foreign language skills, acquire new knowledge and technology to improve their working performance such as professional judgment and skepticism. Meanwhile, the audit firms need to take advantage of becoming partners of international audit firms to ensure the effectiveness of management and control processes. Audit firms' directors should relate the development of audit activities to improve auditor independence. It is a sustainable development orientation because auditor independence is a fundamental requirement of contemporary society and economy toward the audit industry. In addition, the ACPA should put forward an appropriate orientation in the auditors' training to extend the ethical topics such as focusing on the ethical perception of the auditors, performing social responsibility disclosures toward the community, partners, customers and all related parties. In particular, the ACPA recommends enhanced supervision, strictly handles and discloses all serious cases of violations of professional ethics and promotes auditor independence to create a strict legal environment that leads to strong compliance with the professional code of ethics of the international audit industry. 


\section{References}

[1] IFAC, "Handbook of the code of ethics for professional accountants. IFAC," 2016.

[2] Bahram Soltani, "Auditing: An international approach," 2007.

[3] H. Rick, D. Roger, S. Arnold, and W. Philip, Principles of auditing: An introduction to international standards on auditing Prentice Hall, 2014.

[4] G. Gay and R. Simnett, Auditing and assurance services in Australia. Sydney: McGraw-Hill, 2003.

[5] L. D. N. Minh Duc, V. Thi Hoang Yen, N. Hoang Ngoc Thuy, T. Hoang, and A. D. B. Hung, "Enhancing auditors' independence in auditing enterprises in Vietnam," Cogent Economics \& Finance, vol. 7, p. 1602240, 2019.Available at: https://doi.org/10.1080/23322039.2019.1602240.

[6] L. E. DeAngelo, "Auditor independence, 'low balling', and disclosure regulation," Journal of accounting and Economics, vol. 3, pp. 113-127, 1981.Available at: https://doi.org/10.1016/0165-4101(81)90009-4.

[7] M. A. Geiger, D. S. North, and B. T. O'Connell, "The auditor-to-client revolving door and earnings management," Journal of Accounting, Auditing \& Finance, vol. 20, pp. 1-26, 2005.Available at: https://doi.org/10.1177/0148558x0502000101.

[8] T. Adams, J. Krishnan, and J. Krishnan, "Client influence and auditor independence revisited: Evidence from auditor resignations," Journal of Accounting and Public Policy, vol. 40, p. 106846, 2021.Available at: https://doi.org/10.1016/j.jaccpubpol.2021.106846.

[9] B. Adrangi, M. Anderson, and K. Raffiee, "Socioeconomic determinants of drug abuse in the United States," Journal of Social Economics Research, vol. 8, pp. 39-49, 2021.

[10] A. Goldman and B. Barlev, "The auditor-firm conflict of interests: Its implications for independence," The Accounting Review, vol. 49, pp. 707-718, 1974.

[11] A. Mustikarini and D. Adhariani, "In auditor we trust: 44 years of research on the auditor-client relationship and future research directions," Meditari Accountancy Research, 2021.Available at: https://doi.org/10.1108/MEDAR-11-2020-1062.

[12] J. Veuger, "Digitization and blockchain in finance, the Netherlands in 2020 and 2021," International Journal of Applied Economics, Finance and Accounting, vol. 11, pp. 1-22, 2021.Available at: https://doi.org/https://doi.org/10.33094/8.2017.2021.111.1.22.

[13] K. M. Johnstone, T. D. Warfield, and M. H. Sutton, "Antecedents and consequences of independence risk: Framework for analysis," Accounting Horizons, vol. 15, pp. 1-18, 2001.Available at: https://doi.org/10.2308/acch.2001.15.1.1.

[14] J. L. Turner, T. J. Mock, and R. P. Srivastava, "A formal model of auditor independence risk," Australian Accounting Review, vol. 12, pp. 31-38, 2002.

[15] X. Hao, "The relationship between non-audit services and auditor independence: Evidence from Chinese listed companies," Proceedings of Business and Economic Studies, vol. 4, pp. 54-57, 2021.Available at: https://doi.org/10.26689/pbes.v4i1.1860.

[16] R. Ruben, N. Adwa, and Z. Zakaria, "Understanding audit quality \& talent management of auditors in practice through content analysis \& interviews," Humanities and Social Sciences Letters, vol. 8, pp. 78-90, 2020.

[17] N. B. A. Bakar, A. R. A. Rahman, and H. M. A. Rashid, "Factors influencing auditor independence: Malaysian loan officers' perceptions," Managerial Auditing Journal, vol. 20, pp. 804-822, 2005.Available at: https://doi.org/10.1108/02686900510619665.

[18] P. A. Alleyne, D. Devonish, and P. Alleyne, "Perceptions of auditor independence in Barbados," Managerial Auditing Journal, vol. 21, pp. 621-635, 2006.

[19] N. H. Tien, T. M. Thuong, and N. T. H. Yen, "Enhancing independence of local auditing services by profiting from experiences of the Big4 group (KPMG, Deloitte, PWC E\&Y) operating in Vietnam market," Cogent Business \& Management, vol. 6, p. 1605702, 2019.Available at: https://doi.org/10.1080/23311975.2019.1605702.

[20] H. Ndaba, M. Harber, and W. Maroun, "Audit quality implications of regulatory change in South Africa," Journal of Accounting in Emerging Economies, vol. 11, pp. 477-507, 2021.Available at: https://doi.org/10.1108/jaee-11-2020-0290.

[21] T. Ahmed, S. M. Hera, T. J. Rimi, and T. Hassan, "Factors influencing audit expense and quality in an emerging economy: A study on Bangladesh," The Economics and Finance Letters, vol. 7, pp. 179-188, 2020.

[22] R. Akhtar, M. M. Masud, M. S. Uddin, and Q. M. A. Hye, "Underlying drivers that influence farmers' sustainable adaptation strategies," International Journal of Management and Sustainability, vol. 9, pp. 181-193, 2020.

[23] McShane and Von-Glinow, Organizational behaviour. New York: McGraw-Hill Education, 2003.

[24] T. Olalere, "Methodology in accounting research: A critique of taxonomy," SSRN Electronic Journal, 2012.Available at: https://doi.org/10.2139/ssrn.1921192.

[25] S. Viviers, J. Bosch, E. Smit, and A. Buijs, "Is responsible investing ethical?," South African Journal of Business Management, vol. 39, pp. 15-25, 2008.

[26] A. C. Keller, K. T. Smith, and L. M. Smith, "Do gender, educational level, religiosity, and work experience affect the ethical decision-making of US accountants?," Critical Perspectives on Accounting, vol. 18, pp. 299-314, 2007.Available at: https://doi.org/10.1016/j.cpa.2006.01.006.

[27] A. Modarres and A. Rafiee, "Influencing factors on the ethical decision making of Iranian accountants," Social Responsibility Journal, vol. 7, pp. 136-144, 2011.Available at: https://doi.org/10.1108/17471111111114594.

[28] N. Granitz and D. Loewy, "Applying ethical theories: Interpreting and responding to student plagiarism," Journal of Business Ethics, vol. 72, pp. 293-306, 2007.Available at: https://doi.org/10.1007/s10551-006-9171-9.

[29] J. R. Cohen, L. W. Pant, and D. J. Sharp, "Measuring the ethical awareness and ethical orientation of Canadian auditors," Behavioral Research in Accounting, vol. 8, pp. 98-119, 1996.

[30] J. Kujala, A.-M. Lämsä, and K. Penttilä, "Managers' moral decision-making patterns over time: A multidimensional approach," Journal of Business Ethics, vol. 100, pp. 191-207, 2011.

[31] E. J. Kaka, "Covid-19 and Auditing," Journal of Applied Accounting and Taxation, vol. 6, pp. 1-10, 2021.

[32] O. K. Hope and J. C. Langli, "Auditor independence in a private firm and low litigation risk setting," The Accounting Review, vol. 85, pp. 573-605, 2010.Available at: https://doi.org/10.2308/accr.2010.85.2.573.

[33] J. Nunnally and I. Bernstein, Psychometric theory, 3rd ed. vol. 3. New York: McGraw-Hill, 1994. 
[34] V. Beattie, R. Brandt, and S. Fearnley, "Perceptions of auditor independence: UK evidence," Journal of International Accounting, Auditing and Taxation, vol. 8, pp. 67-107, 1999.

[35] F. A. Tahir and Z. Zainal Affrin, "Dimensions of auditor independence: A pilot study," International Journal of Business and Management, vol. 9, pp. 72-76, 2014.Available at: https://doi.org/10.5539/ijbm.v9n6p72.

Appendix-1.

Scale and survey question.

The scale of independent variables is designed according to Likert 5 steps, measured according to the levels:

1. Strongly disagree; 2. Disagree; 3. No comments; 4. Agree; 5. Strongly agree

\begin{tabular}{|c|c|c|c|}
\hline Concept & Variables & Variable measurement & The basis of the scale \\
\hline \multicolumn{4}{|c|}{ Perception of professional ethics } \\
\hline \multirow{3}{*}{ Utilitarianism } & Utilitarianism1 & $\begin{array}{l}\text { The auditor considers the benefits of users of financial } \\
\text { information during the audit process and makes his or } \\
\text { her decisions in accordance with the public interest. }\end{array}$ & \multirow[t]{2}{*}[26,27]{} \\
\hline & Utilitarianism2 & $\begin{array}{l}\text { Auditors are aware of ethical issues that are in the } \\
\text { public interest. }\end{array}$ & \\
\hline & Utilitarianism3 & $\begin{array}{l}\text { The auditor makes decisions that are acceptable to the } \\
\text { public. }\end{array}$ & $(*)$ \\
\hline \multirow{3}{*}{ Deontology } & Deontology1 & $\begin{array}{l}\text { Auditors often consider the provisions of professional } \\
\text { ethical standards or auditing standards to propose } \\
\text { solutions to minimize the dilemmas related to ethical } \\
\text { behavior. }\end{array}$ & \multirow[t]{2}{*}[26,27]{} \\
\hline & Deontology2 & $\begin{array}{l}\text { Auditors comply with applicable laws and regulations } \\
\text { on accounting and auditing standards. }\end{array}$ & \\
\hline & Deontology3 & $\begin{array}{l}\text { Auditors perform the work in such a way that they } \\
\text { think it is widely accepted by the society for the audit } \\
\text { job. }\end{array}$ & $(*)$ \\
\hline \multirow{3}{*}{ Egoism } & Egoism1 & $\begin{array}{l}\text { Auditor make ethical decisions in the work of the } \\
\text { auditor if these things are best for them. }\end{array}$ & \multirow{2}{*}[26,27]{} \\
\hline & Egoism2 & $\begin{array}{l}\text { Auditors determine that the most appropriate } \\
\text { alternative measures for themselves when practicing } \\
\text { the audit. }\end{array}$ & \\
\hline & Egoism3 & $\begin{array}{l}\text { Auditors do things that do not affect their reputation } \\
\text { and professional qualifications. }\end{array}$ & $(*)$ \\
\hline \multicolumn{4}{|c|}{ Ethical perception from the auditing company environment } \\
\hline \multirow{3}{*}{ Philosophy } & Philosophy1 & $\begin{array}{l}\text { Audit company leaders determine compliance with } \\
\text { standards on audit, professional ethics is important. }\end{array}$ & $(*)$ \\
\hline & Philosophy2 & $\begin{array}{l}\text { Audit company leaders determine improving the } \\
\text { quality of auditing is important. }\end{array}$ & $(*)$ \\
\hline & Philosophy3 & $\begin{array}{l}\text { Audit company leaders determine that improving the } \\
\text { good working environment and long-term commitment } \\
\text { for auditors is important. }\end{array}$ & $(*)$ \\
\hline \multirow{4}{*}{ Management } & Management1 & Effective audit process & $(*)$ \\
\hline & Management2 & Effective quality review process & $(*)$ \\
\hline & Management3 & $\begin{array}{l}\text { Specific provisions for situations that threaten to } \\
\text { damage the auditor independence and corresponding } \\
\text { risk mitigation measures }\end{array}$ & $(*)$ \\
\hline & Management4 & $\begin{array}{l}\text { Regulations on sanctions against auditors and assistant } \\
\text { auditors when violating professional ethics }\end{array}$ & $(*)$ \\
\hline \multicolumn{4}{|c|}{ Ethical perception from the direction and control of professional organizations } \\
\hline \multirow{4}{*}{ Monitoring } & Monitoring1 & $\begin{array}{l}\text { Training, updating knowledge related to professional } \\
\text { ethics and audit expertise }\end{array}$ & $(*)$ \\
\hline & Monitoring2 & $\begin{array}{l}\text { Guidance for professional ethics and auditor } \\
\text { independence }\end{array}$ & $(*)$ \\
\hline & Monitoring3 & Supervision of professional organizations & $(*)$ \\
\hline & Monitoring4 & Check quality audit & $(*)$ \\
\hline
\end{tabular}




\begin{tabular}{|c|c|c|c|}
\hline \multirow{3}{*}{ Risk } & Risk1 & $\begin{array}{l}\text { Risk of auditors being fined for losing practicing } \\
\text { certificates }\end{array}$ & \multirow{3}{*}{ [29] } \\
\hline & Risk2 & $\begin{array}{l}\text { Risk of auditors being disciplined by professional } \\
\text { Associations or legal agencies. }\end{array}$ & \\
\hline & Risk3 & $\begin{array}{l}\text { Risk of auditors encountering litigation against } \\
\text { themselves. }\end{array}$ & \\
\hline \multicolumn{4}{|c|}{ Ethical perception from independent auditors } \\
\hline \multirow{3}{*}{ Independence } & Independence1 & $\begin{array}{l}\text { Auditors have not taken any action to harm the auditor } \\
\text { independence during the audit process }\end{array}$ & \multirow{3}{*}[34,35]{} \\
\hline & Independence 2 & $\begin{array}{l}\text { Auditors do not have any perception, attitude, that } \\
\text { harms the objectivity, honesty during the process of } \\
\text { performing the audit. }\end{array}$ & \\
\hline & Independence 3 & $\begin{array}{l}\text { Auditors consider and maintains the "auditing } \\
\text { skepticism of the auditing profession" during the audit } \\
\text { process }\end{array}$ & \\
\hline
\end{tabular}

Appendix-2.

Analysis of convergence of observed variables.

Component Matrix ${ }^{\mathrm{a}}$

\begin{tabular}{|c|c|c|c|c|c|c|c|}
\hline & \multicolumn{7}{|c|}{ Component } \\
\hline & 1 & 2 & 3 & 4 & 5 & 6 & 7 \\
\hline Utilitarian1 & & & 0.689 & & & & \\
\hline Utilitarian2 & & & 0.613 & & & & \\
\hline Utilitarian1 & & & 0.529 & & & & \\
\hline Deontology1 & 0.776 & & & & & & \\
\hline Deontology2 & 0.769 & & & & & & \\
\hline Deontology1 & 0.625 & & & & & & \\
\hline Egoism1 & 0.622 & & & & & & \\
\hline Egoism2 & 0.687 & & & & & & \\
\hline Egoism3 & 0.642 & & & & & & \\
\hline Philosophy1 & & & & & -0.668 & & \\
\hline Philosophy2 & & & & & -0.659 & & \\
\hline $\begin{array}{l}\text { Philosophy3 } \\
\end{array}$ & & & & & & & \\
\hline Management1 & & 0.715 & & & & & \\
\hline Management2 & & 0.659 & & & & & \\
\hline Management3 & & 0.709 & & & & & \\
\hline Management4 & & 0.742 & & & & & \\
\hline Monitoring1 & & & & & & & \\
\hline Monitoring2 & & & & 0.530 & & & \\
\hline Monitoring3 & & & & 0.617 & & & \\
\hline Monitoring4 & & & & 0.679 & & & \\
\hline Risk1 & & & & & & 0.676 & \\
\hline Risk2 & & & & & & 0.640 & \\
\hline Risk3 & & & & & & 0.673 & \\
\hline
\end{tabular}

